\title{
Loss of $\mathrm{N}-\mathrm{myc}$ function results in embryonic lethality and failure of the epithelial component of the embryo to develop
}

\author{
Brian R. Stanton, Archibald S. Perkins ${ }^{1}$, Lino Tessarollo, David A. Sassoon, ${ }^{2}$ and Luis F. Parada ${ }^{3}$ \\ Molecular Embryology and ${ }^{1}$ Molecular Genetics of Oncogenesis Sections, ABL-Basic Research Program, National Cancer \\ Institute-Frederick Cancer Research and Development Center, Frederick, Maryland 21702-1201 USA
}

\begin{abstract}
myc genes are thought to function in the processes of cellular proliferation and differentiation. To gain insight into the role of the $\mathrm{N}$-myc gene during embryogenesis, we examined its expression in embryos during postimplantation development using RNA in situ hybridization. Tissue- and cell-specific patterns of expression unique to $\mathrm{N}$-myc as compared with the related $\mathrm{c}$-myc gene were observed. $\mathrm{N}$-myc transcripts become progressively restricted to specific cell types, primarily to epithelial tissues including those of the developing nervous system and those in developing organs characterized by epithelio-mesenchymal interaction. In contrast, $c-m y c$ transcripts were confined to the mesenchymal compartments. These data suggest that c-myc and $\mathrm{N}$-myc proteins may interact with different substrates in performing their function during embryogenesis and suggest further that there are linked regulatory mechanisms for normal expression in the embryo. We have mutated the $\mathrm{N}$-myc locus via homologous recombination in embryonic stem (ES) cells and introduced the mutated allele into the mouse germ line. Live-born heterozygotes are under-represented but appear normal. Homozygous mutant embryos die prenatally at $\sim 11.5$ days of gestation. Histologic examination of homozygous mutant embryos indicates that several developing organs are affected. These include the central and peripheral nervous systems, mesonephros, lung, and gut. Thus, $\mathbf{N}$-myc function is required during embryogenesis, and the pathology observed is consistent with the normal pattern of $\mathrm{N}$-myc expression. Examination of c-myc expression in mutant embryos indicates the existence of coordinate regulation of myc genes during mouse embryogenesis.
\end{abstract}

[Key Words: N-myc gene; mouse embryogenesis; postimplantation development]

Received August 25, 1992; revised version accepted October 1, 1992.

Genes that are expressed during development and whose biochemical properties are consistent with regulation of cellular proliferation and/or differentiation are ideal candidates for controlling organogenesis. One class of such genes is the proto-oncogenes. Owing to structural or regulatory alteration, oncogenes can perturb the normal regulation of cellular growth and differentiation. Thus, the concept that proto-oncogenes would participate in regulation of these processes has been proposed and studied for many years (for review, see Bock and Marsh 1990). In this study we have attempted to assess the function of the N-myc proto-oncogene during mouse embryonic development.

The myc family of nuclear proto-oncogenes consists of three well-characterized members: c-myc (Vennstrom et al. 1982), N-myc (Kohl et al. 1983; Schwab et al. 1983)

\footnotetext{
${ }^{2}$ Present address: Department of Biochemistry, Boston University School of Medicine, Boston, Massachusetts 02118 USA.

${ }^{3}$ Corresponding author.
}

and L-myc (Nau et al. 1985). c-myc expression has been associated with cellular proliferation, whereas the role of the other myc genes is less clear (Cole 1986). High levels of N-myc RNA, primarily owing to gene amplification, have been observed in tumors of neuroendocrine and embryonic origin such as Wilm's tumor, retinoblastoma, neuroblastoma, and small cell lung carcinoma (Kohl et al. 1983, 1984; Lee et al. 1984; Schwab et al. 1984; Nau et al. 1986). Furthermore, amplification of N-myc in neuroblastoma correlates with an advanced stage of disease and poor prognosis (Brodeur et al. 1984; Thiele et al. 1988). These data have been interpreted to imply a role for $\mathrm{N}-\mathrm{myc}$ in the genesis or progression of these malignancies.

N-myc encodes a nuclear phosphoprotein (Slamon et al. 1986; Ramsey et al. 1987) bearing structural homology to c-myc and exhibits site-specific DNA-binding activity (DePinho et al. 1986; Kohl et al. 1986; Slamon et al. 1986; Stanton et al. 1986; Ramsey et al. 1987; Kerkhoff et al. 1991; Prendergast and Ziff 1991). The 
$\mathrm{N}$-myc protein has a short half-life (Cohn et al. 1990) and contains a number of conserved structural motifs, including basic/helix-loop-helix (Murré et al. 1989) and leucine zipper (Landschulz et al. 1988)-related elements. These protein features are consistent with the $\mathrm{N}-m y c$ protein being a transcriptional regulator whose activity is modulated by direct protein-protein interactions. Support for this notion comes from the observation that both c- and N-myc interact with the human Max (Blackwood and Eisenman 1991) or mouse Myn (Prendergast et al. 1991) protein, and these complexes display increased affinity for specific DNA-binding sites. It is possible that $\mathrm{N}$-myc may interact with additional proteins that are expressed in a tissue-or cell type-specific manner.

Some clues as to the site of action of the $\mathrm{N}$-myc gene product may be garnered by analysis of its expression pattern. Whereas c-myc is expressed in a broad array of cells both in the mammalian embryo and adult (Muller et al. 1982; Pfeifer-Ohlsson et al. 1985; Zimmerman and Alt 1990), N-myc is expressed primarily in the developing embryo (Jakobovitz et al. 1985; Grady et al. 1987; Mugrauer et al. 1988; Downs et al. 1989; Stanton and Parada 1992).

We have compared $\mathrm{N}-m y c$ and c-myc expression to determine the spatial and temporal distribution of transcripts for these genes. The data have suggested that $\mathrm{N}$-myc might function in the development of specific cell lineages of the mammalian embryo. To test this possibility, we employed site-directed mutagenesis via homologous recombination in embryonic stem (ES) cells (Capecchi 1989; Rossant and Joyner 1989; Robertson 1991) to mutate one allele of the endogenous N-myc gene (Stanton et al. 1990). This mutation has been passed through the mouse germ line, and offspring have been generated that are heterozygous for a null $\mathrm{N}-m y c$ allele. These data demonstrate a requirement for the $\mathrm{N}-\mathrm{myc}$ proto-oncogene during murine organogenesis that correlates with its embryonic expression pattern and further provide the first in vivo demonstration of a regulatory interaction among $M y c$ gene family members.

\section{Results \\ Expression analysis}

The overall pattern of $\mathrm{N}-m y c$ and c-myc RNA expression in mouse development was assessed by Northern analysis and by RNA in situ hybridization on embryos ranging from 6.5 to 16.5 days of gestation and is summarized in Figure 1. We observed differential expression patterns for $\mathrm{c}$ - and $\mathrm{N}$-myc from the earliest postimplantation periods analyzed. During the period of development when the definitive germ layers unfold, $\mathrm{N}-m y c$, but not c-myc, is highly expressed in the gastrulating cells that will give rise to the embryo proper. Once somitogenesis and neurulation have commenced, the $\mathrm{N}-m y c$ gene becomes increasingly restricted in its distribution of expression. $\mathrm{Al}$ though c-myc transcripts are present in many tissues at low levels, they are notably reduced or absent in neu- roepithelium (developing brain and spinal cord); a tissue undergoing considerable proliferation that retains high levels of N-myc mRNA (Figs. 1 and 2) N-myc transcript levels are highest in the central nervous system (CNS), cranial and spinal ganglia in the peripheral nervous system (PNS), mandibular and maxillary processes, and heart (Fig. 2C,F). In the developing brain, there is a notable absence of $\mathrm{N}-m y c$ expression in the roof plate neuroepithelium overlying the mesencephalon (Fig. 2).

$\mathrm{N}-m y c$ transcripts are also found in several epithelial cell types during embryogenesis including developing gut, kidney, and lung (Fig. 1). The forming gut comprises two easily distinguishable cell types of endodermal origin: epithelial cells lining the inner lumen of the intestine and the surrounding mesenchyme. $\mathrm{N}-m y c$ transcripts are found in the inner cells corresponding to the lumen (Fig. 2D, F), whereas c-myc transcripts are present in the surrounding mesenchyme (Fig. 2D, E). N-myc transcripts are also present in the luminal (epithelial) cells of the branching lung epithelium that later form bronchioles, whereas c-myc transcripts are confined to the surrounding connective (mesenchymal) cells.

Analysis of a null allele To further explore the role of $\mathrm{N}$-myc during mammalian embryogenesis, we mutated one endogenous allele of this gene in ES cells and generated mice heterozygous for the mutation (Stanton et al. 1990). This mutant $\mathrm{N}-m y c$ allele (designated $\mathrm{N}-m y c^{\mathrm{BRP}}$, is carried in a hybrid genetic background resulting from the random assortment of the ES cell genotype $(129 / \mathrm{Sv})$ and the genotype of the females to which the initial chimeras were bred (C57BL/6JNCr). No appreciable variation of the phenotype described in this work has been observed in the course of four generations of brother/sister matings from which 549 embryos have been examined. We therefore conclude that the $\mathrm{N}$ $m y c^{\mathrm{BRP}}$ allele has full penetrance and is subject to minimal differences in expressivity within this genetic background. Furthermore, we can exclude unlinked secondary mutations in the ES cell-derived component of the genome on the basis of the phenotypic stability observed in mutant embryos over four generations.

Animals were routinely analyzed by Southern analysis of DNA isolated from tail biopsies taken at the time of weaning (see Materials and methods). To date, we have never observed live-born homozygous mutant weanlings resulting from the intercross of heterozygous animals (Fig. 3A). Examination of 549 weaning age animals resulting from the intercross of heterozygous parents have yielded 243 wild-type $(+1+)$ and 306 heterozygous $(+1$ $\mathrm{m})$ progeny, indicating a reduction in survival of heterozygote animals. The surviving heterozygotes do not exhibit overt phenotypes (including deviations in size, weight, fertility, life span, and general health|. Mendelian inheritance would predict $486+/ \mathrm{m}$ progeny, a ratio of $1: 2$ for these two remaining classes of animals (see statistical analysis in Materials and methods).

Embryonic analysis The absence of live-born animals homozygous for the mutant $\mathrm{N}-m y c^{\mathrm{BRP}}$ allele indicated lethality during gestation. To determine the time of death, embryos derived from the intercross of hetero- 


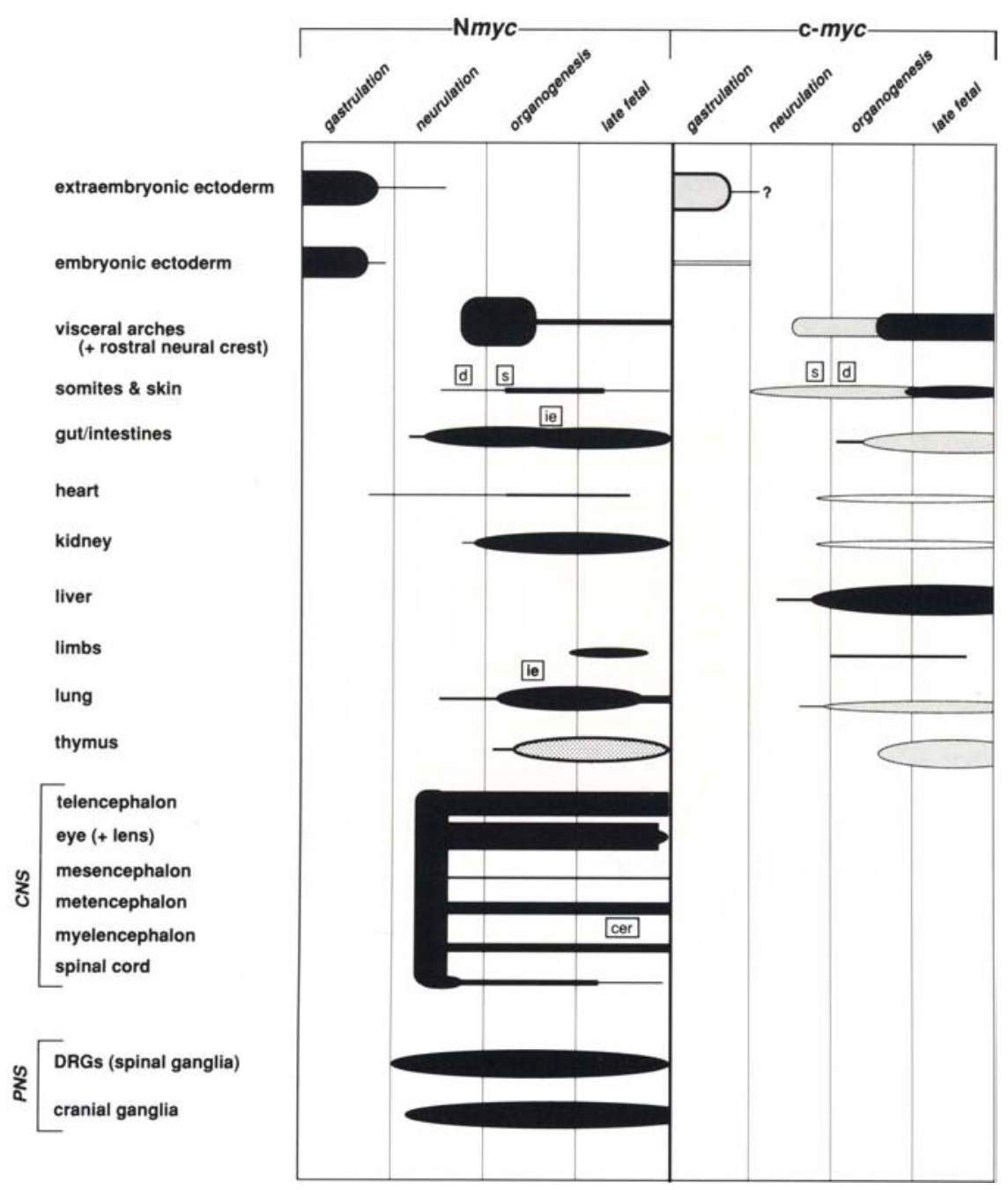

Figure 1. Summary of $\mathrm{N}-\mathrm{myc}$ and $\mathrm{c}-\mathrm{myc}$ expression during mouse embryogenesis. Tissues expressing detectable levels of $\mathrm{N}-m y c$ or c-myc are indicated in the lefthand column. Thickness of the bars and lines indicates relative signal intensity as taken from multiple sections of embryos ranging from 6.5 days postcoitum (p.c.) to birth. For visceral arches, we include rostral neural crest, because these two tissues follow a similar pattern of expression and neural crest components contribute to the developing craniofacial structures. Gastrulation is defined 6.5-8.0 days, neurulation is $8.5-10.5$ days, organogenesis is 11.513.5 days, and late fetal is 14.5 days to birth. Abbreviations used are to indicate subsets of tissues that exhibit expression: (d) Dermatome; (s) sclerotome; (ie) inner epithelium; (cer) cerebellum. Stippled bars indicate tissues that are positive for both myc transcripts but for which close inspection reveals $\mathrm{N}-\mathrm{myc}$ expression in epithelium and $\mathrm{c}-\mathrm{myc}$ in mesenchyme. The pattern of expression of extraembryonic ectoderm was not followed after day 9 p.c. zygous parents were analyzed throughout gestation. Technical considerations precluded genotyping of embryos before embryonic day 8.5 ; however, no apparent morphologic abnormalities were seen in whole-mount or histologic sections of embryonic or extraembryonic tissues in postimplantation embryos from $+/ \mathrm{m}$ intercrosses at or before this stage. The results of this genotypic analysis are represented by the bar chart shown in Figure $4 \mathrm{~A}$, and an example of the Southern analysis of yolk sac-derived embryonic DNA is shown in Figure 4B. The data in Figure 4A comprise analyses of 549 embryos ranging from 9.5 to 18.5 days of gestation and derived from 77 litters that are grouped according to genotype as a percentage of all embryos within each gestational clas's. The relative proportions of the expected progeny resulting from the heterozygous intercross is $\sim 1: 2: 1$ at 9.5 and 10.5 days but thereafter deviates from the expected ratios beginning at day $11.5,(P<0.05)$, indicating a loss of $\mathrm{m} / \mathrm{m}$ embryos (Fig. $4 \mathrm{~A}$ ).

Embryos from the intercross of $+/ \mathrm{m}$ mice were examined morphologically from day 9.0 to day 18.5 , as whole embryos under the dissecting microscope, by scanning electron microscopy, and as hematoxylin-eosin (H-E)stained sections. A total of $26 \mathrm{~m} / \mathrm{m}$ mutant embryos were inspected by examination of $\mathrm{H}$-E-stained sections (nine 9.5-day embryos, five 10.5-day embryos, nine 11.5day embryos, two 12.5-day embryos, and one 15.5-day embryo). Day 9.5 homozygous mutant embryos approximated the size of normal littermates, although departure from normal morphology is first recognizable at this point (see below). Microscopic examination of $\mathrm{m} / \mathrm{m}$ embryos (Fig. 5) revealed thinner embryos in the transverse dimension and morphological differences in several structures, including the roof plate of the myelencephalon, the prosencephalon, and the mandibular arches, as compared with normal littermates. The transverse narrowing of the $\mathrm{m} / \mathrm{m}$ embryo, as well as the mandibular arch hypoplasia (a neural crest-populated structure expressing high $\mathrm{N}-m y c$ levels; Fig. 2C), was also evident following microscopic examination of $\mathrm{H}$-E-stained sections (Figs. 6 and 7). Histologic analysis of the day 9.5 $\mathrm{m} / \mathrm{m}$ embryos revealed other abnormalities, which include a waviness of the neuroepithelium and irregularity of the ectodermal surface. As homozygous mutant em- 


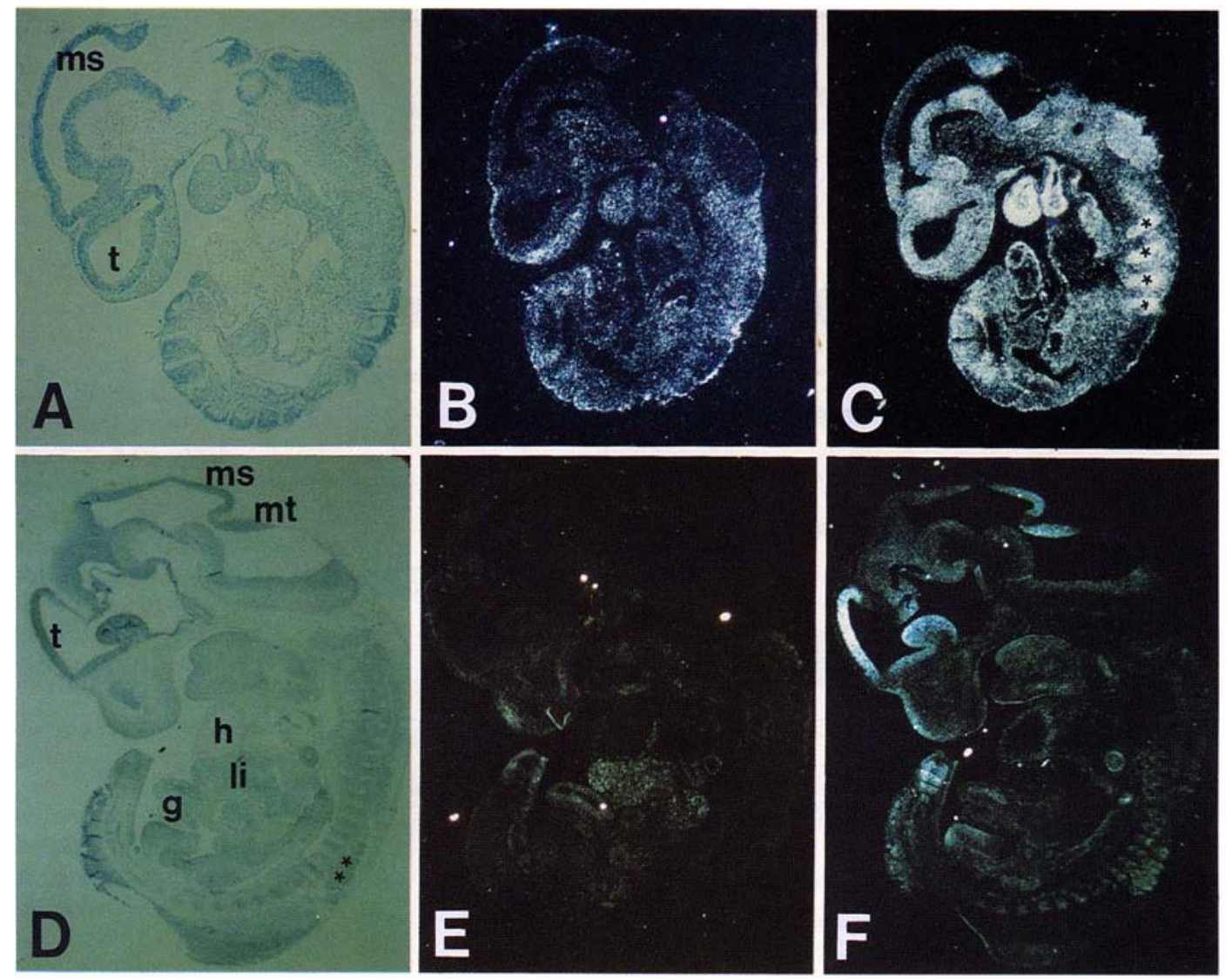

Figure 2. N-myc and c-myc expression in 9.5- and 13-day embryos. $(A)$ Light-field photomicrograph of day 9.5 embryos, showing various CNS structures. $(B)$ Same section as in $A$ hybridized with a c-myc probe and viewed by dark-field optics. $(C)$ Dark-field photomicrograph of an adjacent section to $B$ hybridized with an N-myc probe. Asterisks (*) denote DRG. $(D)$ Light-field photomicrograph of a 13-day embryo hybridized with $\mathrm{N}$-myc. Telencephalon (t), mesencephalon (ms), liver (li), heart (h), and gut (g) are indicated. $(E)$ Adjacent section to $D$ hybridized with c-myc and viewed with dark-field optics. $|F|$ Dark-field view of the same section as in $D$. The gut $(\mathrm{g})$ shows labeling in the epithelial cells lining the lumen.

bryos age past day 9.5, they exhibit progressively greater degrees of morphologic distortion.

Day $10.5 \mathrm{~m} / \mathrm{m}$ embryos are similar in size to normal littermates (Fig. 5), although evidence of growth retardation is already in evidence. Older embryos exhibit greater levels of growth retardation of up to $40 \%$ relative to normal littermates by day 11.5 (Fig. 8). Although some degree of heterogeneity in phenotype was seen in 11.5day $\mathrm{m} / \mathrm{m}$ embryos, their overall characteristics were remarkably consistent. These embryos are extremely fragile and bleed easily, although a beating heart is evident at the initiation of biopsy.

Homozygous mutant embryos can persist in utero past 11.5 days of gestation; however, necrosis was evident in all cases examined indicating a progression toward resorption. The day $12.5 \mathrm{~m} / \mathrm{m}$ embryos that were examined are pale (presumably due to anemia), smaller than the 11.5-day embryos, and no longer show signs of life. The reduced size is most likely due to collapse during the process of necrosis, although on the basis of this static analysis we cannot exclude that the two 12.5-day embryos examined are samples that arrested at an earlier time and were maintained in utero. Combining our observations, we fix day 11.5 of gestation as the time of $\mathrm{m} / \mathrm{m}$ embryogenic arrest.

Histologic analysis of individual organs (see below) revealed that significant and consistent abnormalities were evident at day 10.5 ; and by day $11.5, \mathrm{~m} / \mathrm{m}$ embryos were easily distinguished from normal littermates. Major differences were observed primarily in the developing nervous system, genitourinary system, mandibular arch, gut, and lung. In each of these tissues, we observed appropriate appearance and formation of the primordial organogenic anlagen; however, subsequent proliferation failed to occur resulting in hypoplasia when compared with normal littermates. We also observed reduced thickness in the myocardium of $\mathrm{m} / \mathrm{m}$ embryos, which was most evident at day 11.5 (data not shown).

Nervous system During normal embryonic development, N-myc is expressed throughout the forming neuroepithelium with highest levels in the forebrain, hindbrain, neural tube, and sensory neural crest-derived structures (see Fig. 1). The nervous system was markedly 

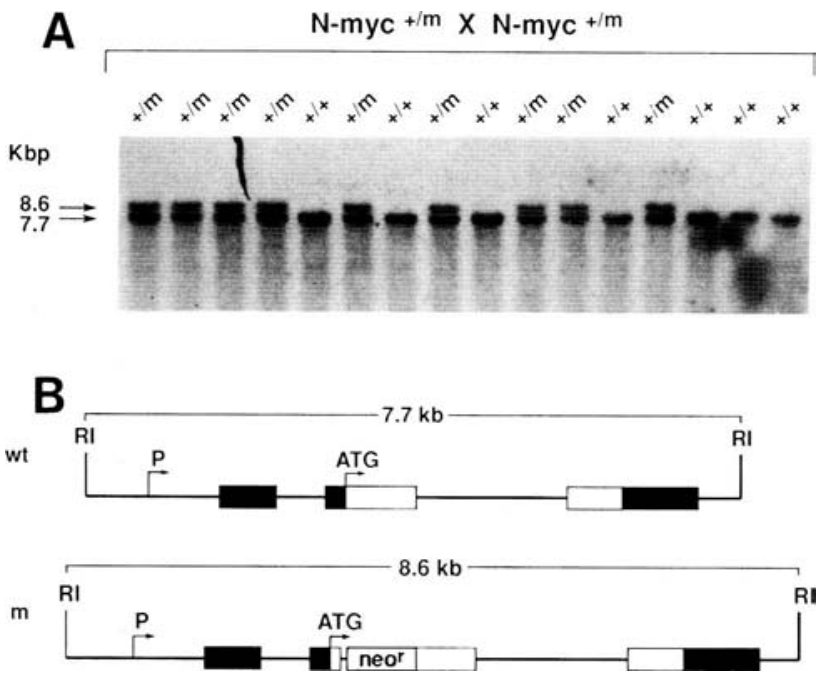

Figure 3. Southern analysis of progeny from $\mathrm{N}-m y c^{\mathrm{BRP}} /+$ heterozygotes. (A) Representative analysis of DNA from weaning age animals, ( 3 weeks of age), resulting from the intercross of animals heterozygous for the mutant $\mathrm{N}-m y c$ allele. DNA was isolated from tail biopsies as described in Materials and methods and digested with EcoRI. The presence of the wild-type allele is indicated by a $7.7-\mathrm{kbp}$ band, and that of the mutant band by an $8.6-\mathrm{kbp}$ band. The genotype of each animal is indicated above each lane. $(+)$ Wild-type allele; $(\mathrm{m})$ the $\mathrm{N}-\mathrm{myc} \mathrm{c}^{\mathrm{BRP}}$ allele. $(B)$ Schematic representation of the wild-type $(t o p)$ and mutant (bottom) allele of $\mathrm{N}-m y c\left(\mathrm{~N}-\mathrm{myc}^{\mathrm{BRP}}\right)$. The two differ only by insertion of the neo-coding sequences (Stanton et. al. 1990). The expected band size resulting from hybridization with an $\mathrm{N}$-myc-specific probe is indicated.

affected by mutation of the N-myc locus (Figs. 7 and 9) We did not observe a quantifiable reduction in the number of mitotic figures; however, day 11.5 mutant em- bryos exhibited a general hypoplasia of the telencephalic structures: sites of high $\mathrm{N}-m y c$ expression. The neuroepithelium was thinner in the mutant and did not attain the same level of architectural complexity normally evident in the ventricular folds of normal embryos. Neurite outgrowths from PNS ganglia were severely under-represented, particularly in the trigeminal $\left(V^{\text {th }}\right.$ cranial $)$ and the dorsal root ganglia (DRG; Fig. 9). In general, the cranial ganglia of homozygous mutant embryos were reduced in size, and the mitotic rate was $<25 \%$ of normal controls. A similar, yet less dramatic, reduction in size was seen in the DRG where the emanating nerve tracts were severely curtailed. Thus, structural deficiencies were found in neuronal tissues that normally exhibit high levels of $\mathrm{N}-m y c$ expression.

Genitourinary system The development of the genitourinary system is also affected by mutation of the $\mathrm{N}$-myc locus (Fig. 10). The entire mesonephros is disorganized, and defects may be seen in three areas: the mesonephric tubules, the adjacent dorsal aorta, and the genital ridge. The initial formation of the mesonephric duct and tubules at day 9.5 appears to be slightly delayed in some, but not all, homozygous mutants /data not shown). However, the subsequent growth and organization appears deficient in the $\mathrm{m} / \mathrm{m}$ embryos. Figure 10 compares the genital ridges and mesonephros of mutant and normal embryos at day 11.5 , and two changes are evident. First, although some tubules appear normal in mutant embryos, others have either failed to form or have undergone premature degeneration in the homozygous mutant (Fig. 10C), which is not evident in the normal embryos (Fig. 10D). In extreme cases, while initial epithelial condensation occurs, mesonephric tubule formation is not observed (data not shown). Apoptosis is a normal feature in the transient existence of mesonephric
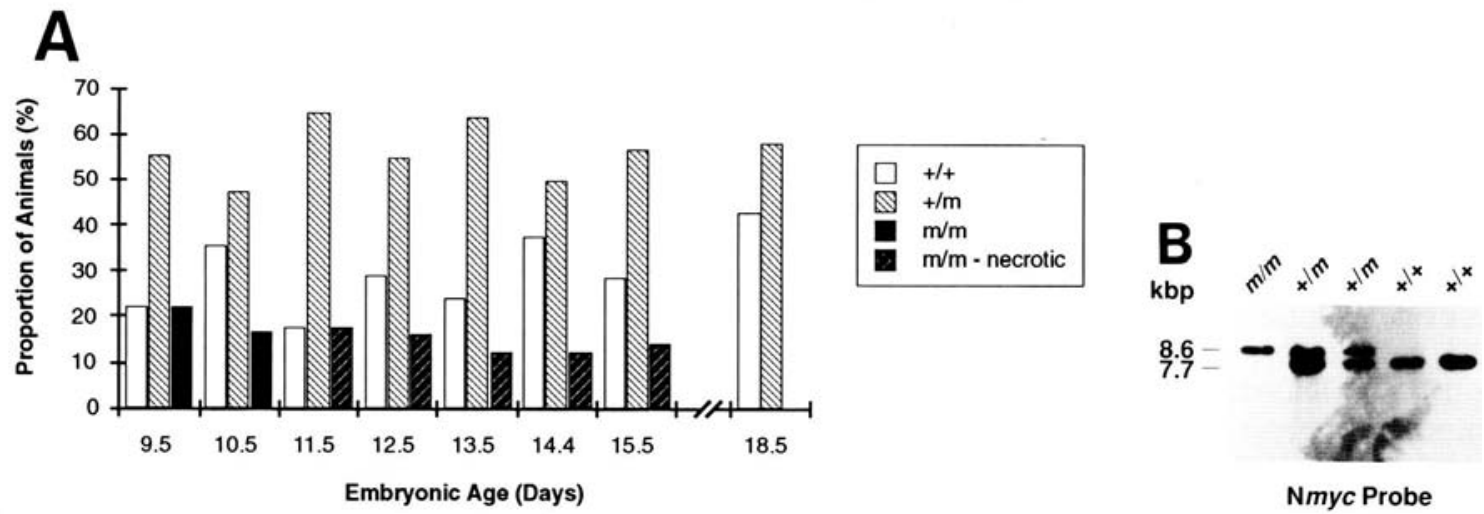

Figure 4. (A) Genotype $(+/+,+/ \mathrm{m}, \mathrm{m} / \mathrm{m})$, present in embryos of varying gestational ages from 9.5 to 15.5 days. Cumulative genotype data from analysis of 549 embryos derived from 77 litters were sorted by gestational age. The percentage of embryos of each genotype is plotted. (Open boxes) Wild-type animals; (hatched boxes) heterozygous animals; (solid boxes) homozygous mutant animals. Overtly necrotic embryos are indicated by dark hatching. Slashed X-axis indicates that this analysis did not include embryos of 16.5 or 17.5 days of gestation. $(B)$ Representative Southern analysis. Yolk sac DNA was obtained as described in Materials and methods and analyzed as in Fig. 3 . The genotype of each embryo as interpreted from the analysis is shown above each lane, where $\mathrm{m}$ indicates the presence of the $\mathrm{N}-m y c^{\mathrm{BRP}}$ allele and + indicates the presence of the wild-type N-myc locus. DNA from a homozygous mutant $(\mathrm{m} / \mathrm{m})$ embryo contains only the $8.6-\mathrm{kbp}$ EcoRI fragment. 
E 10.5
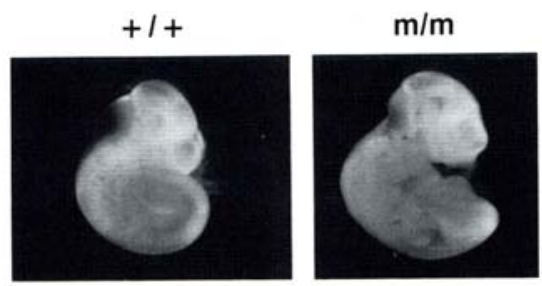

E 11.5
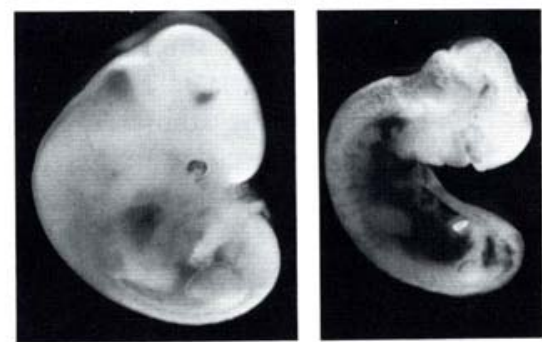

E 12.5
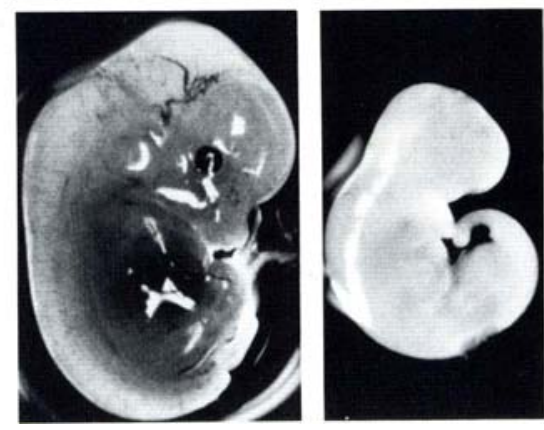

Figure 5. Microscopic examination of unfixed embryos comparing wild-type $(+1+)$ and homozygous mutant $(\mathrm{m} / \mathrm{m})$ embryos. Embryos were dissected free from extraembryonic membranes at 10.5, 11.5, and 12.5 days of gestation and photographed at $30 \times$. Representative homozygous wild-type $(+1+1$ and mutant $(\mathrm{m} / \mathrm{m})$ embryos are shown for each stage of development. Vascular disruption seen in the day $11.5(\mathrm{~m} / \mathrm{m})$ embryo is typical.

structures; therefore, it is possible that apoptotic events are initiated prematurely in the mesonephros of mutant embryos.

The mesenchyme surrounding the mesonephric tubules appears hypoplastic in $\mathrm{m} / \mathrm{m}$ embryos. This may be the result of a failure of appropriate inductive epithelial/ mesenchymal interactions to occur or may be a structural consequence of compression by the neighboring dorsal aorta, which is dilated in $\mathrm{m} / \mathrm{m}$ embryos (Fig. 10).

Further evidence of abnormality in the mesonephros of day $11.5 \mathrm{~m} / \mathrm{m}$ embryos is hypoplasia of the genital ridge (Fig. 10A, B). This ridge is indistinguishable in mutant and normal embryos until day 10.5 whereupon the mutant ridges fail to progress. In addition, the adjacent coelomic epithelium has a "hobnail" appearance and is more irregular than in the normal embryos, indicating a loosening of intercellular attachments, which is likely a reflection of a generalized degenerative phenomenon.

Lung Normal lung development initiates at day 9.0 of embryogenesis as a ventral out-pouching of endodermderived cells of the foregut. This out-pouching then ex- tends into an epithelial tube-like structure that divides and branches. $\mathrm{N}-m y c$ is normally expressed throughout the lung epithelium, with highest levels in the terminal regions of the branching tubules (Fig. 1).

In both $\mathrm{m} / \mathrm{m}$ and normal embryos, the morphology of these structures is identical at day 9.5 and numerical assessment of mitoses was the same (Fig. 11). However, by day 10.5, normal embryos (Fig. 11F) have extended these structures farther caudally than observed in $\mathrm{m} / \mathrm{m}$ embryos (Fig. 11E) and have initiated the process of branching that results in the arborized network of bronchi and bronchioles. Mutant $(\mathrm{m} / \mathrm{m})$ embryos (Fig. 11E) fail to exhibit branching morphogenesis and remain simple tube-like structures. Though decreased in number relative to genotypically normal littermates, mitoses are present in the epithelia of the unbranched anlagen. No morphologic abnormalities were noted in the mesenchymal component of the mutant lung, suggesting that the abnormal development is inherent to the epithelial component.

Gut We have failed to detect any evidence of stomach or large intestine formation in $\mathrm{m} / \mathrm{m}$ embryos. Although foregut and cloacal epithelia are present early, as
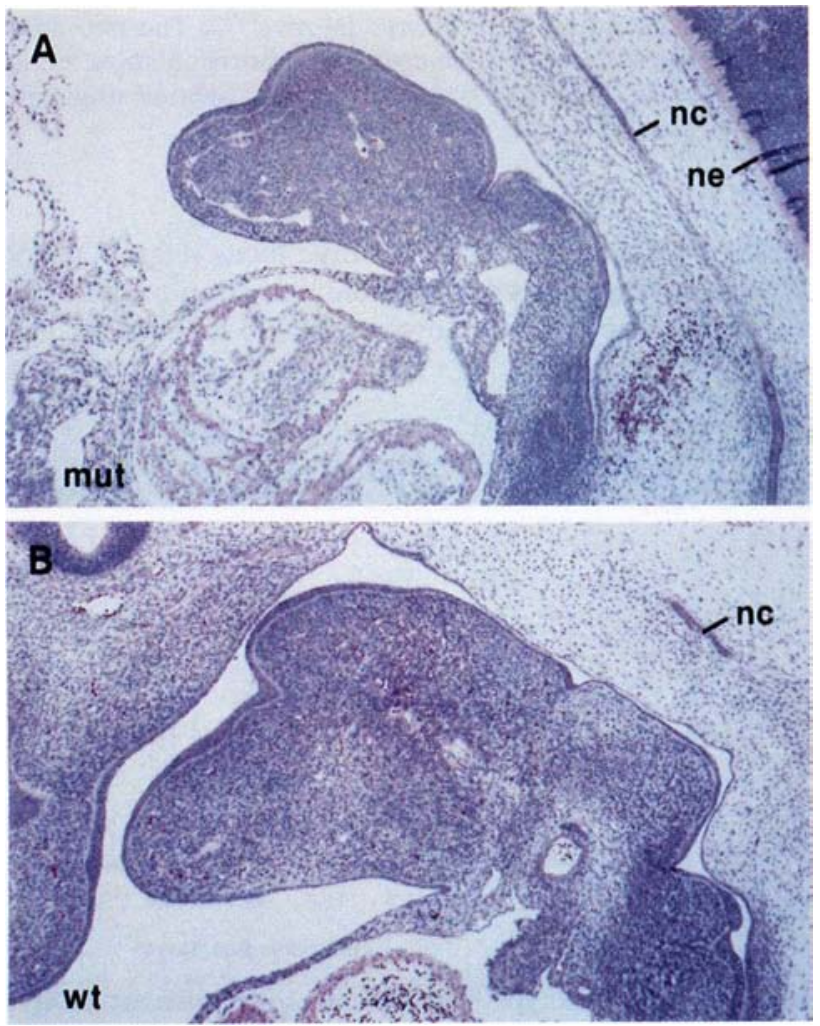

Figure 6. Comparison of mandibular arch development in 11.5-day embryos. Midsagittal sections through 11.5-day homozygous mutant $(\mathrm{m} / \mathrm{m}, A)$ and wild-type $(+/+, B)$ embryos were examined. The region of the mandibular arch was photographed through a $30 \times$ objective. Location of the notochord (nc) is shown for reference. (ne) Neneuroepithelium. 


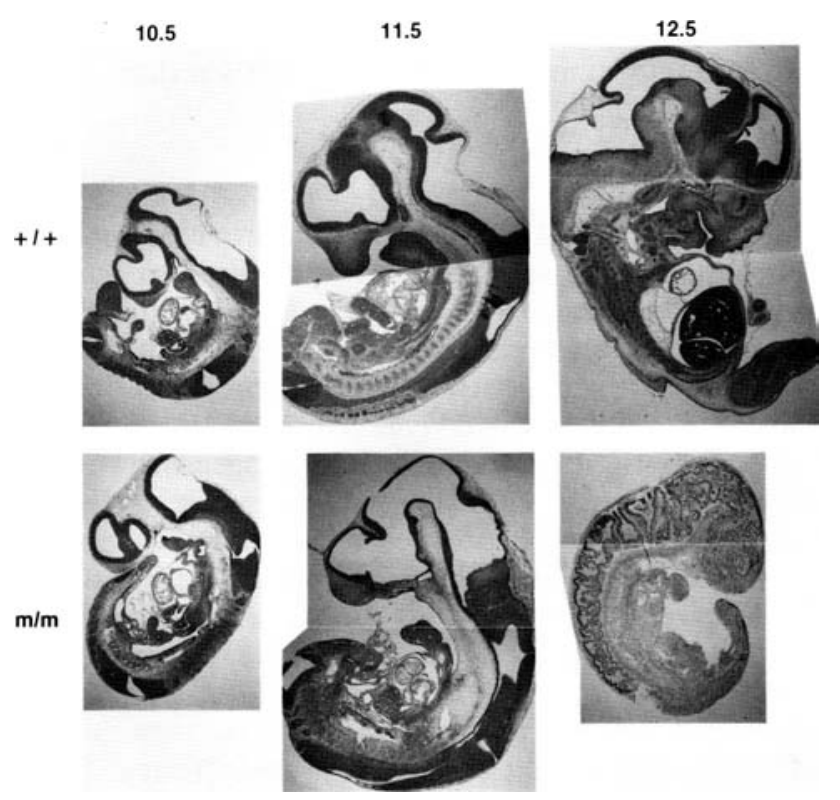

Figure 7. Sagittal sections through 10.5-, 11.5-, and 12.5-day wild-type $(+1+1$ and homozygous mutant $(\mathrm{m} / \mathrm{m})$ embryos. Embryos were dissected free of extraembryonic membranes and processed as described in Materials and methods. Sections of 4 $\mu \mathrm{m}$ were prepared from paraffin-embedded material, stained with $\mathrm{H}-\mathrm{E}$ and photographed. Representative sections are shown.

evidenced by lung induction, the stomach and large intestine, midgut derivatives that normally express high levels of $\mathrm{N}$-myc (Fig. $2 \mathrm{~F}$ ) are either absent or so disorganized in mutant $(\mathrm{m} / \mathrm{m})$ embryos that we fail to recognize evidence of these structures in histological sections.

Analysis of c-myc expression in $\mathrm{m} / \mathrm{m}$ embryos One of the more striking results from our comparative in situ

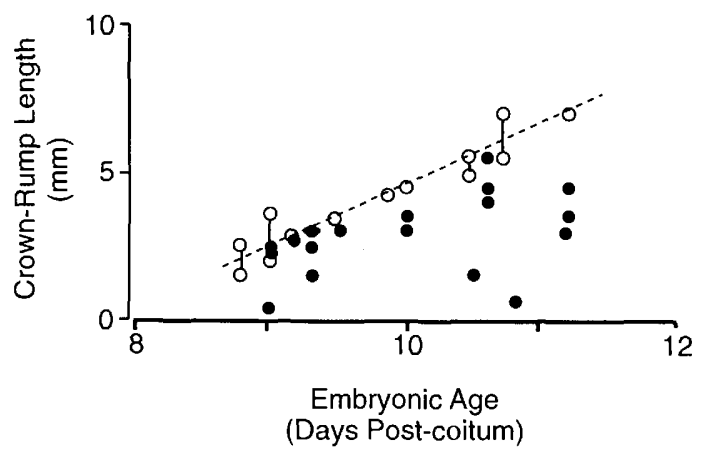

Figure 8. Crown-rump size comparison of homozygous mu$\operatorname{tant}(\mathrm{m} / \mathrm{m})$ and other classes of embryos $(+/+$ and $+/ \mathrm{m})$. Measurements were taken on fixed embryos and plotted against gestational age. (O, wild-type) The average litter size of a given age. Where multiple litters of the same gestational age were of different average size, the maximum and minimum sizes are plotted and connected by a vertical line. Individual $(\mathrm{m} / \mathrm{m}) \mathrm{em}$ bryos were measured and assigned to a gestational age class based on measurement of normal littermates. These embryos were then plotted on the same graph $(\boldsymbol{O}$, mutant $)$.
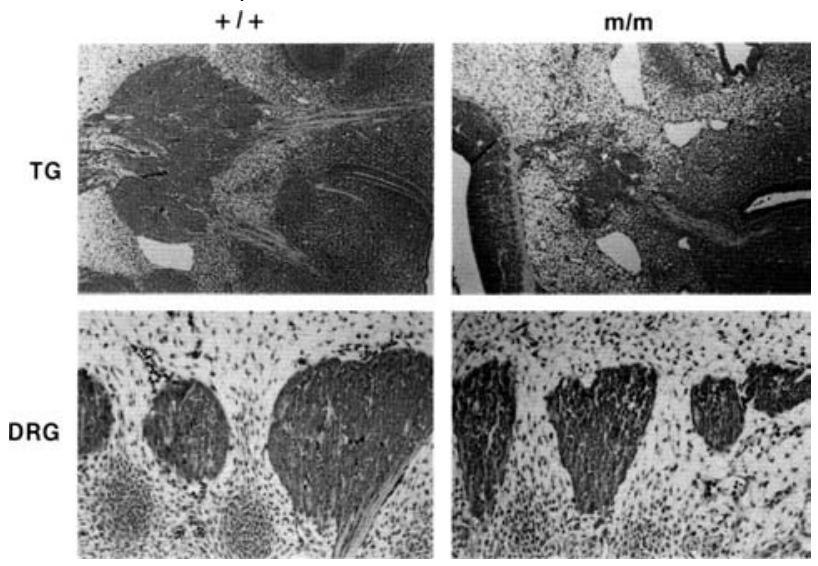

Figure 9. Comparison of trigeminal (TG) and dorsal root (DRG) ganglion development between wild-type $(+1+)$ and homozygous mutant $(\mathrm{m} / \mathrm{m})$ embryos. Medial sections through the trigeminal ( $\mathrm{V}^{\text {th }}$ cranial; top, TG) and mid-thoracic dorsal root (bottom, DRG) ganglia are shown for wild-type $(+1+1$ and mutant $(\mathrm{m} / \mathrm{m})$ 10.5-day embryos.

studies with $\mathrm{N}-m y c$ and c-myc probes was the paucity of coexpression in embryonic tissues, raising the possibility that some form of feedback cross-regulation might exist between the two genes. We investigated c-myc expression in the CNS of null embryos, where N-myc is normally present at high levels and c-myc levels are below detection (Fig. 1). A sagittal section of a 10.5-day $\mathrm{m} / \mathrm{m}$ embryo hybridized with a c-myc probe is shown in Figure 12B, contrasted with an equivalent section from a normal $1+1+\mid$ embryo, which is shown in Figure 12D. c-myc expression has not been observed previously in the the developing neuroepithelium (Fig. 2). However, in this case, the neuroepithelium of the mutant embryo (Fig. 12A,B) expresses appreciable levels of c-myc transcript. Figure 12, C and D, shows the section from a normal littermate that was present on the same tissue slide as that in Figure 12A, thus confirming the absence of $\mathrm{c}-\mathrm{myc}$ transcripts in neuroepithelium and controlling against possible artifacts in the hybridization process.

These results demonstrate that the $\mathrm{N}-m y c$ and c-myc genes are coordinately regulated in the neuroepithelium of normal developing embryos. In this tissue, the presence of high $\mathrm{N}-m y c$ levels results in the repression of the c-myc locus. Inactivation of the $\mathrm{N}-m y c$ locus allows expression of the c-myc gene (Fig. 12A).

\section{Discussion}

In this report we describe our current progress in understanding the function of the $\mathrm{N}-m y c$ proto-oncogene during embryogenesis. We initially chose this gene for study on the basis of three criteria: (1) N-myc is closely related to c-myc, a widely expressed gene implicated in cell proliferation; (2) $\mathrm{N}-m y c$ expression is primarily confined to the embryo (Jakobovitz et al. 1985; Zimmerman et al. 
1986); and (3) N-myc is associated with a limited set of embryonic and neuroendocrine tumors (Kohl et al. 1984; Lee et al. 1985; Nau et al. 1988; Nisen et al. 1988). We reasoned that by analogy with c-myc, N-myc might have related functions in regulating cell growth, but perhaps in a more specialized subset of cells during embryonic development.

\section{Mutually exclusive embryonic expression}

A surprising outcome of this study is the finding that c-myc and $\mathrm{N}-m y c$ transcripts are often maintained in distinct embryonic compartments throughout development. Both genes exhibit a reduction in RNA levels during mid-gestation, although changes in $\mathrm{N}$-myc levels are more substantial. At the organismal level, N-myc RNA predominates in the CNS and PNS, where c-myc transcripts are rarely present. c-myc RNA tends to be more heterogeneously distributed, although high levels are maintained in liver throughout development, an organ where $\mathrm{N}-m y c$ transcripts are undetected. At the cellular level, the two genes rarely appear to be coexpressed; rather, when both gene transcripts are present in the same tissue (i.e., lung, kidney, gut), c-myc transcripts are found in the mesenchymal component while N-myc transcripts are located in the luminar, epithelial cells. These observations, coupled with the prevailing notion that myc genes play key roles in cellular proliferation, suggest that $\mathrm{N}-m y c$ and $c-m y c$ are essential for the proliferation of separate elements of the embryo. These data further raised the possibility that coordinate or intergenic regulation of $\mathrm{N}-m y c$ and $\mathrm{c}-m y c$ expression might exist during vertebrate embryogenesis. It is intriguing that although expressed throughout the neuroepithelium, N-myc transcripts are always absent in the devel- oping midbrain. It is possible that the third myc family member, L-myc, may be expressed in this region.

\section{Embryonic lethality}

Generation of a null N-myc allele has provided a means to begin exploring some of the issues raised by our expression studies in greater detail. Given the complex and regulated expression pattern found for $\mathrm{N}-m y c$ during development, we anticipated that this gene would be required for embryonic survival. However, a surprising number of studies using targeted mutagenesis via homologous recombination have reported subtle, undetectable, or unexpected phenotypes in the resultant homozygous mice. Examples of this include the $\beta 2$-microglobulin gene, $\operatorname{PrP}$, src, fyn, and fos, among others (Zijlstra et al. 1990; Schwarzberg et al. 1991; Soriano et al. 1991; Tybülewicz et al. 1991; Büeler et al. 1992; E. Wagner, pers. comm.). Thus, a gratifying result has been the observation that in the null homozygote $\mathrm{N}-\mathrm{myc}^{\mathrm{BRP}} / \mathrm{N}$ $m y c^{\mathrm{BRP}}$, deficiencies were present in most embryonic structures where this gene is normally expressed. A notable departure from this trend occurs during gastrulation, which appears to proceed normally in null embryos in the absence of $\mathrm{N}-m y c$, even though this gene and not c-myc is normally expressed in the rapidly proliferating embryonic ectoderm. These data indicate that $\mathrm{N}-m y c$ is not required for normal gastrulation or that its function at this stage is fortuitously compensated by other genes.

\section{$N$-myc is required for normal organogenesis}

Homozygous null embryos apparently develop normally until after the onset of organogenesis. We can first detect abnormalities in homozygous mutants by 9.5 days when
Figure 10. Comparison of kidney development in 11.5-day wild-type and homozygous mutant embryos. $(A, C)$ Sections through homozygous mutant (mut, $\mathrm{m} / \mathrm{m}$ ) embryos. $(B, D)$ Sections through wild-type (wt) embryos. (gr) Genital ridge; (mt) mesonephric tubule; (ce) coelomic epithelium, (st) stomach. $A$ and $B$ were taken through a $10 \times$ objective; $C$ and $D$ were taken through a $19 \times$ objective.
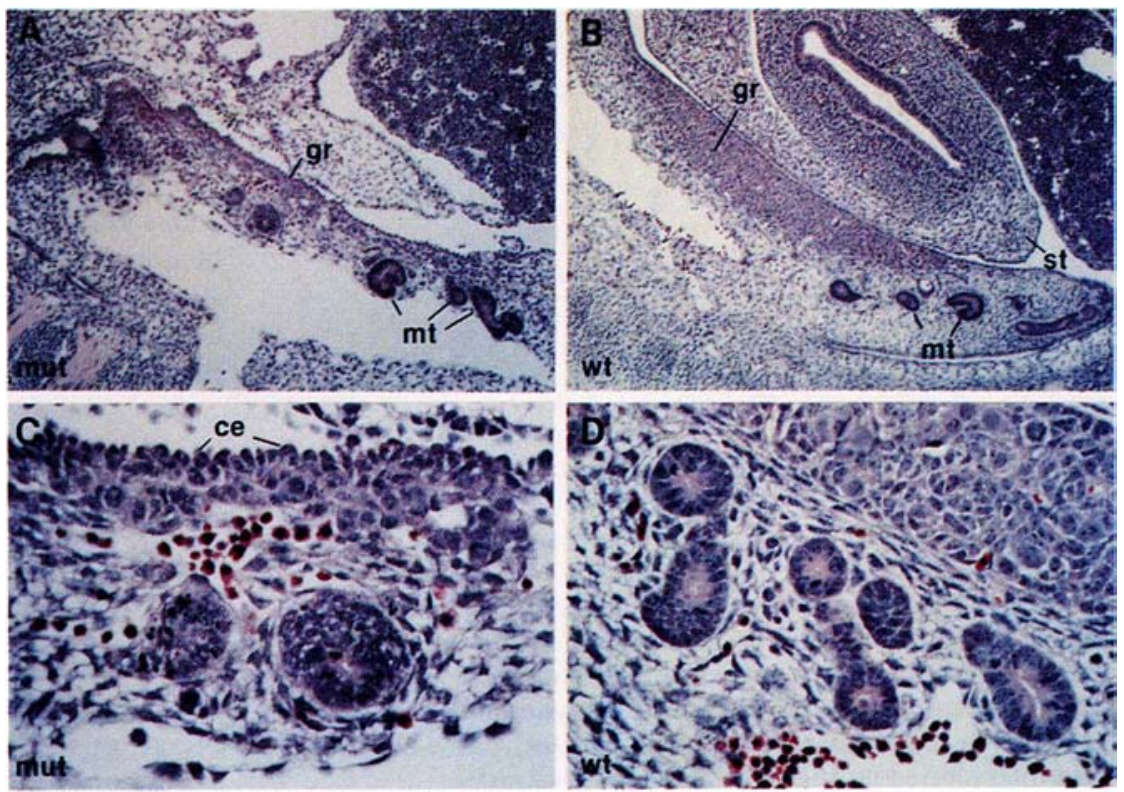

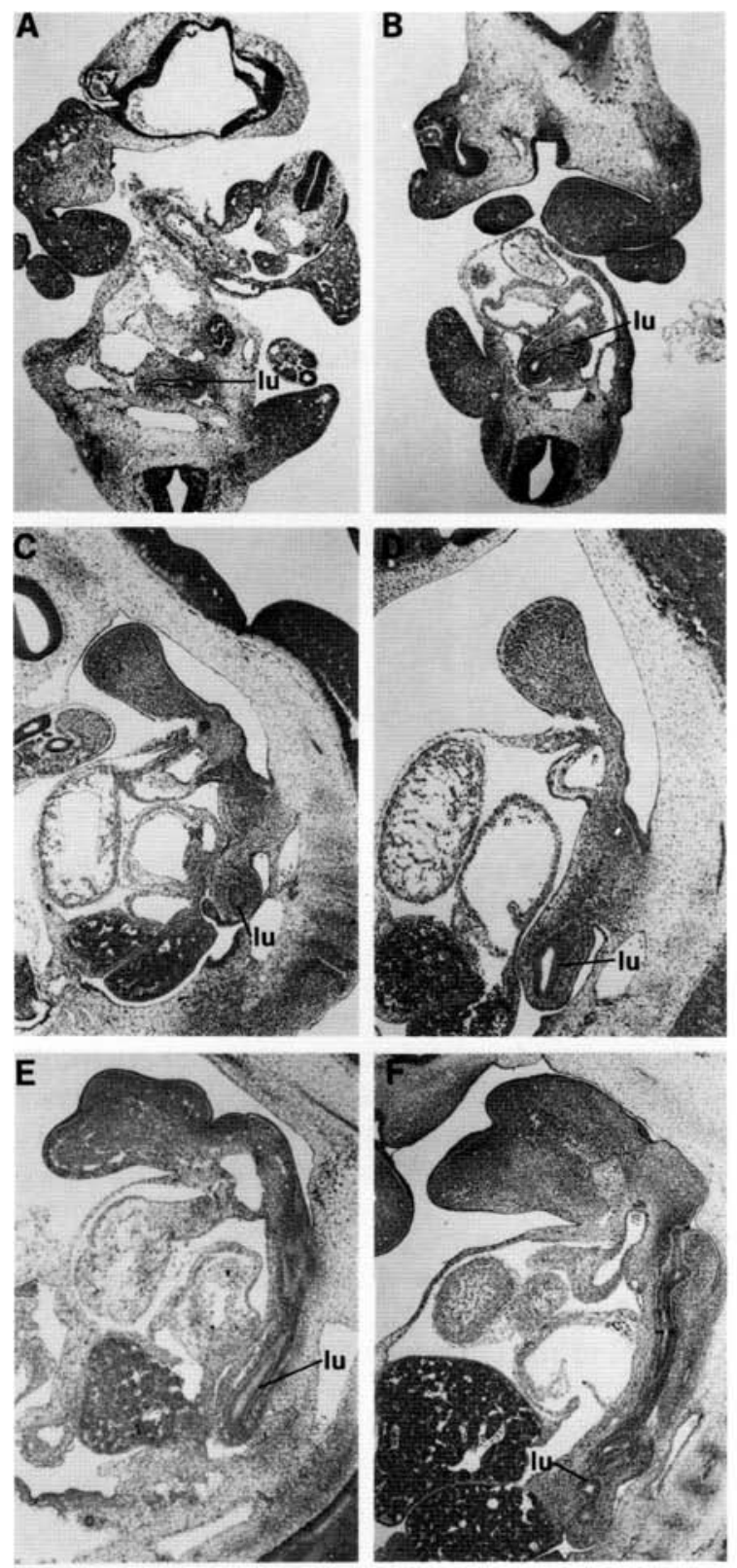

Figure 11. Comparison of lung development between wildtype and homozygous mutant embryos. $\langle A, C, E\}$ Sections through homozygous mutant $(\mathrm{m} / \mathrm{m})$ embryos. $(B, D, F)$ Sections through wild-type $(+1+)$ embryos. $(A, B)$ Day 9.5 embryos; $(C, D)$ day 10.5 embryos; $(E, F)$ day 11.5 embryos. The location of the developing lung is indicated (lu). All views were taken through a $5 \times$ objective.

these embryos begin to display a constellation of pathologic features that strongly suggests an important role for $\mathrm{N}-\mathrm{myc}$ in the proliferation of differentiated or partially differentiated structures. The predominant hallmark is hypoplasia, which affects a number of organ systems, particularly those of epithelial origin. Within endoderm. derived structures, most notable are the hypoplastic gut and lung. In mutant embryos, we have been unable to identify structures of the midgut and lower gut that are normally present in 10.5- to 11.5-day embryos. This developmental retardation, together with our observation that $\mathrm{N}-\mathrm{myc}$ is normally transcribed in the epithelium of the nascent gut, provides compelling evidence for an essential role in the growth and/or organization of gut epithelium. In addition, the epithelium of mutant lung fails to undergo appropriate branching as compared with lung of wild-type littermates, which shows multiple branchings at embryonic day 11.5. Recently, Moens and co-workers (1992) have described a hypomorphic allele of $\mathrm{N}-m y c\left(\mathrm{~N}-\mathrm{myc}^{9 \mathrm{a}}\right)$, which results in neonatal death in a homozygous state. Analysis of the $\mathrm{N}-m y c^{9 a}$ homozygotes revealed improper branching of the embryonic lung, coupled with selectively reduced expression of $\mathrm{N}-m y c$ in this tissue. These data are entirely consistent with our in situ studies and with the phenotype that we observe in lung of $\mathrm{N}-\mathrm{myc}^{\mathrm{BRP}}$ homozygotes. By extension, the work of Moens and co-workers provides support for our interpretation of the cause of abnormalities observed in other embryonic tissues where $\mathrm{N}$-myc expression is ablated by the $\mathrm{N}-m y c^{\mathrm{BRP}}$ null allele.

The genital ridge, together with the mesonephros, was also affected by the $\mathrm{N}-m y c^{\mathrm{BRP}}$ mutation. We and others (Mugrauer et al. 1988) have noted $\mathrm{N}$-myc expression in the epithelia of induced embryonic kidney structures. Although mesonephric tubules were evident in mutant embryos, they were decreased in number and size and showed an increased amount of pyknosis, presumably representing apoptosis. The thickness of the genital ridge was markedly diminished and existed as a thin wisp of tissue lying between the coelomic epithelium and the dorsal aorta, which appeared consistently dilated in the mutant embryos. Both the stromal and germ cell components of the genital ridge were hypoplastic in the mutant, being reduced to approximately one-tenth the size of those in normal littermates. Similar deficiencies were observed in the CNS and PNS, sites of normal N-myc expression. Lack of organization and cell number reduction were most evident in several neural crest-derived structures, including trigeminal ganglia and DRG, and pharyngeal pouches. All of these characteristics lead to the conclusion that $\mathrm{N}-m y c$ functions to allow proliferation of epithelial components of the organogenic embryo.

We have observed that the stage in development at which arrest occurs in mutant embryos varies within about a 24-hr window between embryonic days 10.5 and 11.5. However, none of the deficiencies described thus far provide a satisfactory explanation for the cause of embryonic death. Although possibly structurally deleterious, the absence of normal lung, gut, PNS, and so forth, should not affect embryonic viability but, rather, survival after birth. Perhaps the best clue for cause of morbidity lies in the observation that the homozygous mutant embryos bleed easily upon manipulation (Fig. 5), exhibit distended aortas, and are severely anemic when examined at embryonic day 12 . These observations suggest a failure in the developing cardiovascular system, leading to spontaneous bleeding that would result in em- 
Figure 12. Expression of c-myc in neuroepithelium of homozygous mutant $\mathrm{N}$-myc embryos. $\langle A, C\rangle$ Dark-field and ${ }^{\star} B, D \mid$ bright-field view of sagittal sections through the head of 10.5 - day $\mathrm{m} / \mathrm{m}(A, B)$ and $+/+\{C, D\rangle$ mouse embryos. The section was hybridized with a c-myc-specific RNA probe as described in Materials and methods. The embryos used in this experiment were from the same litter and were embedded in a single paraffin block. Note that $B$ is a photograph of the identical $\mathrm{m} / \mathrm{m}$ embryo from the adjacent section $(5 \mu \mathrm{m})$ to that of $A, C$, and $D$ because the tissue in $A$ was partially damaged.
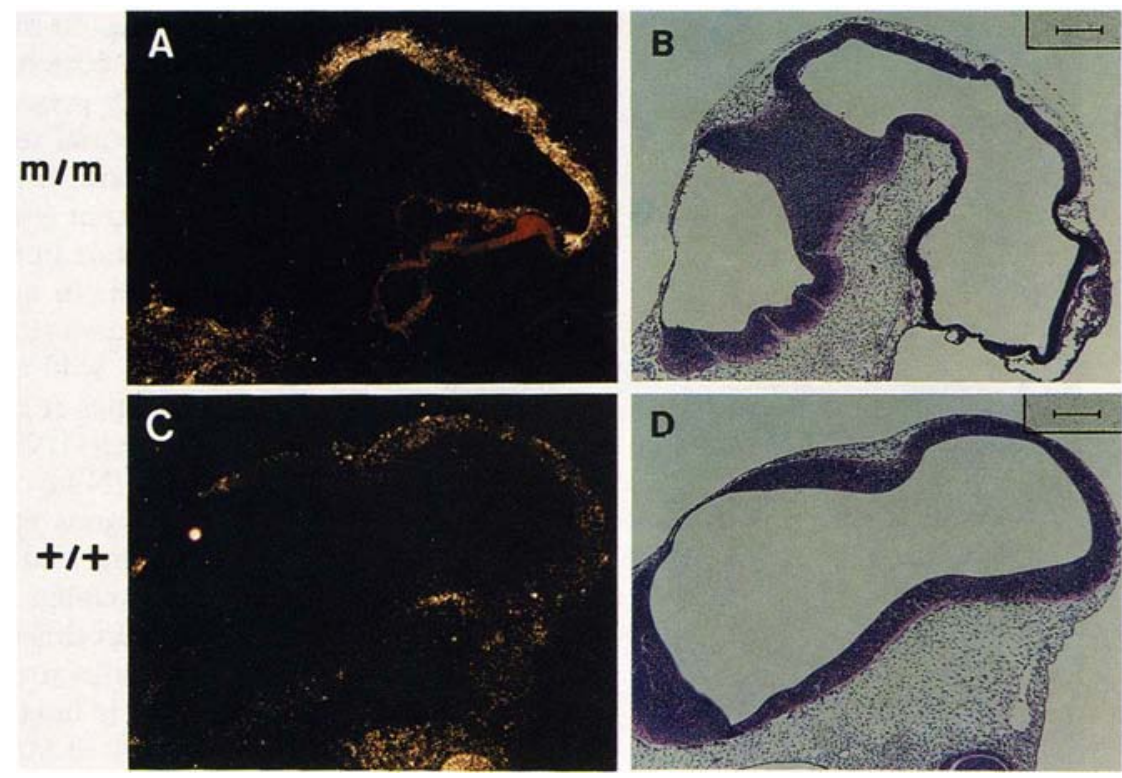

bryonic death. We have detected subtle signs of heart abnormalities in the myocardium, a site of $\mathrm{N}-\mathrm{myc}$ expression, which appears thin in the mutants.

\section{Heterozygotes exhibit reduced fitness}

Adult heterozygous animals do not exhibit any observable phenotype, although there is a numerical reduction in the proportion of animals that carry only one wildtype gene. The disappearance of these embryos occurs late in gestation or soon after birth, as the expected numbers of $+/ \mathrm{m}$ embryos are present through embryonic day 18.5 yet are significantly reduced by postnatal day 21 . We (Stanton et al. 1990) and others (Sawai et al. 1991) have shown that the level of expression is reduced by twofold in ES cells carrying a single functional N-myc gene. Although it is difficult to obtain a meaningful assessment of the degree of $\mathrm{N}-m y c$ mRNA production in each individual organ of heterozygote embryos, it is likely that some heterozygotes fail to progress during a period when a threshold level of $\mathrm{N}$-myc product is required in a critical organ that is sensitive to minor fluctuations. The lung is a good candidate based on the observations by Moens et al. (1992) in mice homozygous for the hypomorphic $\mathrm{N}-m y c^{9 a}$ allele. The basis for the reduced number of $+/ \mathrm{m}$ mice and the precise timing of death is currently under investigation.

\section{Intergenic regulation}

One impetus for generating $\mathrm{N}-\mathrm{myc}$ mutant mice was to assess the possibility of cross-regulation among $M y c$ family genes. This was based on our expression studies and on previous work with transgenic models suggesting the existence of direct negative cross-regulation between $\mathrm{N}$-myc and c-myc (Dildrop et al. 1988; Rosenbaum et al. 1989). These workers observed that overexpression of
$\mathrm{N}-m y c$ in transgenic mice resulted in the down-regulation of the endogenous c-myc and N-myc genes. In situ analysis of c-myc expression in homozygous mutant embryos reveals that c-myc is expressed in neuroepithelium, a site where it is not normally present. These data provide firm evidence for the existence of cross-regulation of these genes in at least some cell types. Continuing analysis of c-myc and L-myc expression in these embryos and generation of primary cell cultures should provide useful reagents for studies of regulation and proliferation. Future studies based on the use of this model system should provide a unique resource for examining development of the epithelial components that are critical to the organogenic phase of mammalian development.

\section{Materials and methods}

\section{In situ hybridization}

Protocols were as described previously (Martin-Zanca et al.' 1990; Tessarollo et al. 1992) using ${ }^{35}$ S-labeled cRNA probes. After hybridization and washes, the slides were dehydrated and dipped in Kodak NTB-2 emulsion, stored for 5-10 days at $4^{\circ} \mathrm{C}$, and developed in Kodak D-19. Probes were derived from regions of the mouse $\mathrm{N}$-myc gene that did not hybridize to other members of the myc gene family at low stringency. A partial N-myc cDNA was isolated from an embryonic library prepared with day 10.5 mouse embryonic RNA (LeMouellic et al. 1988) using a genomic probe (gift from Fred Alt, Howard Hughes Medical Institute, Boston, MA). An antisense RNA probe was transcribed from the T7 promoter after linearizing with HincII. The resulting 800-bp riboprobe is unique for $\mathrm{N}-\mathrm{myc}$. A sense-strand riboprobe was hybridized to adjacent or nearby sections from those presented in this study, and no labeling above background was ever detected (data not shown). The $c-m y c$ probe was a 400-bp BamHI-BglII fragment derived from the c-myc-specific first exon. This plasmid was kindly provided by Michael Cole and is described by Baumbach and co-workers (1988). All RNA 
probes labeled with ${ }^{35} \mathrm{~S}$ were prepared by standard procedures (Kreig and Melton 1987).

\section{DNA analysis}

The details of the mutagenesis of the N-myc locus in ES cells has been described (Stanton et al. 1990). The mutated N-myc locus differs from the wild-type allele by the addition of $\sim 850$ bp of neo sequences (Fig. 3), resulting in the size increase of an EcoRI N-myc hybridizing band from 7.7 to $8.6 \mathrm{kbp}$ (Stanton et al. 1990). Genotypes of all animals and embryos were determined by Southern analysis using the entire N-myc insert from pN7.7 (DePinho et al. 1986) as a probe. This genomic fragment contains sequences both $5^{\prime}$ and $3^{\prime}$ of those present in the recombination cassette. Results were confirmed using a neo-specific probe that hybridizes only to the mutant allele.

Genomic DNA was prepared from tail biopsies and yolk sacs by conventional proteinase $\mathrm{K} /$ phenol extraction (Jenkins et al. 1982), and DNA was digested with restriction enzymes as recommended by the manufacturer (Boehringer Mannheim Biochemicals). Southern blot procedures were as described in Stanton et al. (1990).

\section{Mice and embryos}

Pups were weaned at 3 weeks postpartum, and tail biopsies were taken at 4 weeks. Heterozygote $m /+$ animals were systematically intercrossed by brother/sister matings for embryo analysis. The morning of the detection of a vaginal plug was considered day 0.5 , upon which gestational age was assigned. At the time of embryo biopsy, morphologic criteria, as indicated by Brown (1990), were used in assigning developmental age. Key criteria included somite number, limb bud, eye and ear development, and crown-rump length. The genotype of each embryo was determined by analysis of yolk sac-derived DNA. The embryos were then fixed overnight, dehydrated, and embedded in paraffin (Hogan et al. 1986). Embryos were sectioned at 4-5 $\mu \mathrm{m}$ thickness, mounted on gelatin-treated slides, and stained with H-E. Photography was done using a Wild Heerbrugg stereomicroscope equipped with a Nikon N2000 camera containing Ektar 125 or TMAX 100 film (Kodak). Histologic sections were photographed using a Zeiss Axiophot microscope with integral camera and similar film.

\section{Assignment of gestational age via crown-rump measurements}

The gestational age was calculated by interpolation of the average crown-rump length of $+/+$ and $+/ \mathrm{m}$ embryos within a single litter against a standard curve (broken line) generated using data taken from Rugh (1968), as shown in Figure 8. Crown-rump measurements were made of each embryo examined and plotted against this curve. The average crown-rump length of each litter was then plotted against the age curve, and a developmental age assignment was made for that litter. This age was then used for placing the crown-rump measurement obtained from mutant and wild-type embryos. In cases where significant variation of embryo length between litters was observed, the range of lengths used in the averaging assignment is shown by a vertical line connecting the wild-type measurements (Fig. 8).

\section{Statistical analysis}

To determine the statistical significance of the reduced number of heterozygous $(+/ \mathrm{m})$ progeny resulting from the intercrosses, a chi-square $\left(\mathrm{X}^{2}\right)$ analysis was performed. The genotypes of 549 progeny, with a distribution of $243+/+$ and $306+/ \mathrm{m}$, were obtained. No live-born $\mathrm{m} / \mathrm{m}$ progeny were observed. To calculate the $\mathrm{X}^{2}$ value for the remaining classes of animals, 243 was taken as the expected number of $+/+$ animals and 486 was taken for the $+/ \mathrm{m}$ class. A- $\mathrm{X}^{2}$ value of 66.6 was calculated. Using one degree of freedom, this value indicates significant deviation from values predicted by Mendelian inheritance at $P<0.005$. [Alternative calculations, in which the total number of progeny obtained (549) was used for computation of expected numbers of progeny $(183$ for $+/+$ and 366 for $+/ \mathrm{m})$, also resulted in $\mathrm{X}^{2}$ values that indicate significant deviation at the $P<0.005$ level.]

\section{Acknowledgments}

We thank Susan W. Reid and Janet A. Blair for their excellent technical assistance, the members of the Parada laboratory for many useful discussions, and Cindy Fitzpatrick for manuscript preparation. Research was sponsored by the National Cancer Institute, Department of Health and Human Services, under contract NO1-CO-74101 with ABL. The contents of this publication do not necessarily reflect the views or policies of the Department of Health and Human Services, nor does mention of trade names, commercial products, or organizations imply endorsement by the U.S. Government.

The publication costs of this article were defrayed in part by payment of page charges. This article must therefore be hereby marked "advertisement" in accordance with 18 USC section 1734 solely to indicate this fact.

\section{References}

Baumbach, W.R., E.M. Colston, and M.D. Cole. 1988. Integration of the Balb/c ecotropic provirus into the colony-stimulating factor-1 growth factor locus in a myc retrovirus-induced murine monocyte tumor. J. Virol. 62: 3151-3155.

Blackwood, E.M. and R.N. Eisenman. 1991. Max: A helix-loophelix protein that activates transcription through the immunoglobulin enhancer mE3 motif. Genes \& Dev. 4: 167-179.

Bock, G. and J. Marsh. eds. 1990. Proto-oncogenes in cell development. Ciba Foundation Symposium 150. John Wiley and Sons, Ltd. New York.

Brodeur G.M., R.C. Seeger, M. Schwab, H.E. Varmus, and J.M. Bishop. 1984. Amplification of N-myc in untreated human neuroblastomas correlates with advanced disease stage. Science 224: 1121-1124.

Brown, N.A. 1990. Routine assessment of morphology and growth: Scoring systems and measurement of size. In Postimplantation mammalian embryos: A practical approach. (ed. A.J. Copp and D.L. Cockroft), pp. 93-1108. IRL/Oxford University Press, New York.

Büeler, H., M. Fischer, Y. Lang, H. Bluethmann, H.-P. Lipp, S.J. DeArmond, S.B. Prusiner, M. Aguet, and C. Weissmann. 1992. Normal development and behaviour of mice lacking the neuronal cell-surface PrP protein. Nature 356: 577-581.

Capecchi, M.R. 1989. Altering the genome by homologous recombination. Science 244: 1288-1292.

Cohn, S.L., H. Salwen, M.W. Quansney, N. Ikegaki, J.M. Cowan, C.V. Herst, R.H. Kennett, S.T. Rosen, J.A. DiGiuseppe, and G.M. Brodeur. 1990. Prolonged N-myc halflife in a neuroblastoma cell line lacking N-myc amplification. Oncogene 5: 1821-1827.

Cole, M.D. 1986. The myc oncogene: Its role in transformation and differentiation. Annu. Rev. Genet. 20: 361-384. 
DePinho, R.A., E. Legouy, L.B. Feldman, N.E. Kohl, G.D. Yancopolous, and F.W. Alt. 1986. Structure and expression of the murine N-myc gene. Proc. Natl. Acad. Sci. 83: 1827-1831.

Dildrop, R., K. Zimmerman, R.A. DePinho, G.D. Yancopoulos, A. Tesfaye, and F.W. Alt. 1988. Differential expression of myc-family genes during development: Normal and deregulated N-myc expression in transgenic mice. Curr. Top. Microbiol. Immunol. 141: 100-109.

Downs, K.M., G.R. Martin, and J.M. Bishop. 1989. Contrasting patterns of $m y c$ and $\mathrm{N}-m y c$ expression during gastrulation of the mouse embryo. Genes \& Dev. 3: $860-869$.

Gossler, A., T. Doetschman, R. Korn, E. Serfling, and R. Kemler. 1986. Transgenesis by means of blastocyst-derived embryonic stem cell lines. Proc. Natl. Acad. Sci. 83: 9065-9069.

Grady, E.F., M. Schwab, and W. Rosenau. 1987. Expression of N myc and c-src during development of fetal human brain. Cancer Res. 47: 2933-2936.

Hogan, B., F. Constantini, and E. Lacy. 1986. Manipulating the mouse embryo: A laboratory manual. Cold Spring Harbor Laboratory, Cold Spring Harbor, New York.

Jakobovitz, A., M. Schwab, J.M. Bishop, and G.R. Martin. 1985. Expression of $\mathrm{N}$ myc in teratocarcinoma stem cells and mouse embryos. Nature 318: 188-191.

Jenkins, N.A., N.G. Copeland, B.A. Taylor, and B.K. Lee. 1982. Organization, distribution, and stability of endogenous ecotropic murine leukemia virus DNA in chromosomes of Mus musculus. I. Virol. 43: 26-36.

Kerkhoff, E., K. Bister, and K.H. Klempnauer. 1991. Sequence specific DNA binding by myc proteins. Proc. Natl. Acad. Sci. 88: $4323-4327$.

Kohl, N.E., N. Kanda, R.R. Schrenk, G. Bruns, S.A. Latt, F. Gilbert, and F.W. Alt. 1983. Transposition and amplification of oncogene related sequences in human neuroblastomas. Cell 35: 3659-3673.

Kohl, N.E., C.E. Gee, and F.W. Alt. 1984. Activated expression of the $\mathrm{N} \mathrm{myc}$ gene in human neuroblastomas and related tumors. Science 226: 1335-1337.

Kohl, N.E., E. Legouy, R. DePinho, P. Nisen, R. Smith, C. Gee, and F.W. Alt. 1986. Human N myc is closely related in organization and nucleotide sequence to c-myc. Nature 319: 73-77.

Kreig, P.A. and D.A. Melton. 1987. In vitro RNA synthesis with SP6 RNA polymerase. Methods Enzymol. 155: 397-415.

Landschulz, W., P. Johnson, and S. McKnight. 1988. The leucine zipper: A hypothetical structure common to a new class of DNA binding proteins. Science 240: 1759-1764.

Lee, W.H., A.L. Murphree, and W.F. Benedict. 1984. Expression and amplification of the $\mathrm{N} m y c$ gene in primary retinoblastoma and related tumors. Nature 309: 458-460.

LeMouellic, H., H. Candamine, and P. Brulet. 1988. Patterns of transcription of the homeo gene Hox-3.1 in the mouse embryo. Genes \& Dev. 2: 125-135.

Martin-Zanca, D., M. Barbacid, and L.F. Parada. 1990. Expression of the trk proto-oncogene is restricted to the sensory cranial and spinal ganglia of neural crest origin in mouse development. Genes \& Dev. 4: 683-694.

Moens, C.B., A.B. Auerbach, R.A. Conlon, A.L. Joyner, and J. Rossant. 1992. A targeted mutation reveals a role for $\mathrm{N}-m y c$ in branching morphogenesis in the embryonic mouse lung. Genes \& Dev. 6: 691-704.

Mugrauer, F., F.W. Alt, and P. Ekblom. 1988. N myc protooncogene expression during organogenesis in the developing mouse as revealed by in situ hybridization. J. Cell Biol. 107: 1325-1335.

Muller, R., D.J. Slamon, J.M. Tremblay, M.J. Cline, and I.M. Verma. 1982. Differential expression of cellular oncogenes during pre- and postnatal development of the mouse. Nature 299: 640-649.

Murré, C., P. McCaw, and D. Baltimore. 1989. A new DNA binding and dimerization motif in immunoglobulin enhancer binding, daughterless, myoD and myc proteins. Cell 56: $777-783$.

Nau, M.M., B.J. Brooks, J. Battey, E. Sausville, A.F. Gazdar, I.R. Kirsch, O.W. McBride, V. Bertness, G.F. Hollis, and J.D. Minna. 1985. L-myc, a new myc-related gene amplified and expressed in human small cell lung cancer. Nature 318: 6973.

Nau, M.M., B. Brooks, D. Carney, D. Gazdar, J. Battey, E. Sausville, and J. Minna. 1986. Human small-cell lung cancers show amplification and expression of the $\mathrm{N}$ myc gene. Proc. Natl. Acad. Sci. 83: 1092-1096.

Nisen P.D., P.G. Waber, M.A. Rich, S. Pierce, J.R. Garvin, F. Gilbert, and P. Lanzkowsky. 1988. N-myc oncogene RNA expression in neuroblastoma. J. Natl. Cancer Inst. 80: 16331637.

Pfeifer-Ohlsson, S., J. Rydnert, A.S. Goustin, E. Larsson, C. Betsholtz, and R. Ohlsson. 1985. Cell-type specific pattern of myc proto-oncogene expression in developing human embryos. Proc. Natl. Acad. Sci. 82: 5050-5054.

Prendergast, G.C. and E.B. Ziff. 1991. Methylation-sensitive sequence-specific DNA binding by the $\mathrm{c}-\mathrm{myc}$ basic region. $\mathrm{Sci}$ ence 251: 186-189.

Prendergast, G.C., D. Lawe, and E.B. Ziff. 1991. Association of Myn, the murine homolog of Max, with c-myc stimulates methylation-sensitive DNA binding and Ras co-transformation. Cell 65: 395-407.

Ramsey, T., L. Stanton, M. Schwab, and J.M. Bishop. 1987. Human proto-oncogene $\mathrm{N}$ myc encodes nuclear proteins that bind DNA. Mol. Cell. Biol. 6: 4450-4457.

Robertson, E.J. 1991. Using embryonic stem cells to introduce mutations into the mouse germ line. Biol. Reprod. 44: 238245.

Rosenbaum, H., E. Webb, J.M. Adams, S. Cory, and A.W. Harris. 1989. N-myc transgene promotes B lymphoid proliferation, elicits lymphomas and reveals cross-regulation with c-myc. EMBO I. 8: 749-755.

Rossant, J. and A.L. Joyner. 1989. Towards a molecular-genetic analysis of mammalian development. Trends Genet. 5: 277283.

Rugh, R. 1968. The mouse: Its reproduction and development. p. 302. Burgess Publishing Co., Minneapolis, MN.

Sawai, S., A. Shimono, K. Hanaoko, and H. Kondoh. 1991. Embryonic lethality resulting from disruption of both N-myc alleles in mouse zygotes. New Biol. 3: 861-869.

Schwab, M., K. Alitalo, K.-H. Klempnauer, H.E. Varmus, J.M. Bishop, G. Brodeur, M. Goldstein, and J. Trent. 1983. Amplified DNA with limited homology to myc cellular oncogene shared by human neuroblastoma cell lines and a neuroblastoma tumor. Nature 305: 245-248.

Schwab, M., J. Ellison, M. Busch, W. Rosenau, H.E. Varmus, and J.M. Bishop. 1984. Enhanced expression of the human gene $\mathrm{N}$ myc consequent to amplification of DNA may contribute to malignant progression of neuroblastoma. Proc. Natl. Acad. Sci. 81: 4940-4944.

Schwartzberg, P.L., A.M. Stall, J.D. Hardin, K.S. Bowdish, T. Humaran, S. Boast, M.H. Harbison, E.J. Robertson, and S.P. Goff. 1991. Mice homozygous for the $a b l^{\mathrm{ml}}$ mutation show poor viability and depletion of selected $B$ and $T$ cell populations. Cell 65: 1165-1172.

Slamon, D.J., T.C. Boone, R.C. Seeger, D.E. Keith, V. Chazin, H.C. Lee, and L.M. Souza. 1986. Identification and characterization of the protein encoded by the human $\mathrm{N}$ myc on- 
cogene. Science 232: 768-772.

Soriano, P., C. Montgomery, R. Geske, A. Bradley. 1991. Targeted disruption of the c-src proto-oncogene leads to osteopetrosis in mice. Cell 64: 693-702.

Stanton, B.R. and L.F. Parada. 1992. The N-myc proto-oncogene: Developmental expression and in vivo site-directed mutagenesis. Brain Path. 2: 71-83.

Stanton, L., M. Schwab, and J.M. Bishop. 1986. Nucleotide sequence of the human $\mathrm{N}$ myc gene. Proc. Natl. Acad. Sci. 83: $1772-1776$.

Stanton, B.R., S.W. Reid, and L.F. Parada. 1990. Germ line transmission of an inactive $\mathrm{N}$ myc allele generated by homologous recombination in mouse embryonic stem cells. Mol. Cell. Biol. 10: 6755-6758.

Tessarollo, L., L. Nagarajan, and L.F. Parada. 1992. c-ros: The vertebrate homolog of the sevenless tyrosine kinase receptor is tightly regulated during organogenesis in mouse development. Development 115: 11-20.

Thiele, C.J., L. Cazenave, J.B. Bolen, and M.A. Israel. 1988. Developmentally regulated genes in neuroblastoma. Prog. Clin. Biol. Res. 271: 185-194.

Tybülewicz, V.L.J., C.E. Crawford, P.K. Jackson, R.T. Bronson, and R.C. Mulligan. 1991. Neonatal lethality and lymphopenia in mice with a homozygous disruption of the c-abl protooncogene. Cell 65: 1153-1163.

Vennstrom, B., D. Sheiness, J. Zabielski, and J.M. Bishop 1982. Isolation and characterization of $\mathrm{c}-m y c$, a cellular homolog of the oncogene $(\mathrm{v}-\mathrm{myc})$ of avian myelocytomatosis virus strain 29. J. Virol. 42: 773-776.

Zijlstra, M., M. Bix, N.E. Simister, J.M. Loring, D.H. Raulet, and R. Jaenisch. 1990. $\beta 2$-microglobulin deficient mice lack CD4-8 ${ }^{+}$cytolytic T cells. Nature 344: 742-746.

Zimmerman, K. and F.W. Alt. 1990. Expression and function of myc family genes. Crit. Rev. Oncol. 2: 75-95.

Zimmerman, K., G. Yancopolous, R. Collum, R. Smith, N.E. Kohl, K. Denis, M. Nau, O. Witte, D. Toran-Allerand, C. Gee, J. Minna, and F.W. Alt. 1986. Differential expression of myc family genes during murine development. Nature 319: $780-783$. 


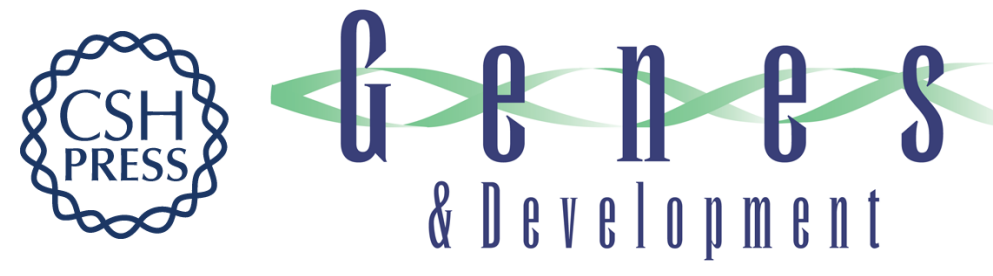

\section{Loss of $\mathrm{N}$-myc function results in embryonic lethality and failure of the epithelial component of the embryo to develop.}

B R Stanton, A S Perkins, L Tessarollo, et al.

Genes Dev. 1992, 6:

Access the most recent version at doi:10.1101/gad.6.12a.2235

References This article cites 53 articles, 23 of which can be accessed free at:

http://genesdev.cshlp.org/content/6/12a/2235.full.html\#ref-list-1

License

Email Alerting

Service

Receive free email alerts when new articles cite this article - sign up in the box at the top right corner of the article or click here.

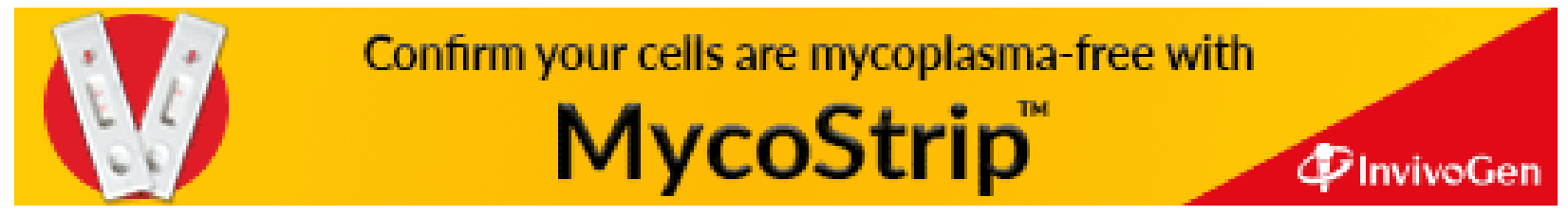

